\title{
THE INTEGRATION OF BUSINESS MODELS AS PART OF PRE-MERGER AND ACQUISITIONS IN THE POLISH SECTOR OF MANAGEMENT INFORMATION SYSTEMS
}

\author{
Jolanta Wartini-Twardowska ${ }^{1}$, Zbigniew Twardowski ${ }^{2}$
}

\begin{abstract}
This paper presents the methodology of assessing opportunities and threats related to the combining of heterogeneous business models in complex organizations (enterprise groups) from the point of view of added value. The main objective was to develop a methodology for assessing the risk of including a company with a specific business model within a complex organization. The authors carried out an in-depth analysis of mutual influences for fifteen typical business models. Guided by their original approach to classifying business models in the sector for management information systems, the authors used the cross-impact method to rank models in the value chain of this sector. The operational processes of the business models were also identified. The proposed methodology allows for a relatively accurate assessment of the impact of particular operational processes of one model upon the strategic objectives of another. The study established a set of data enabling the determination of the potential risks of combining two distinct sector models, the 'integrator' and the 'added value reseller', as a enterprise group. The methodology presented in this paper could be used to develop a computer system supporting strategic decisions regarding the allocation of resources in complex organizations.
\end{abstract}

JEL Classification Numbers: G34, L86 DOI: http://dx.doi.org/10.12955/cbup.v4.744

Keywords: business model, merger \& acquisition, sector of management information systems.

\section{Introduction}

The management information systems (MIS) sector, as part of the technology and communication (T\&C) sector, is characterized by significant technological progress, which strongly affects other industries and governments (Central Statistical Office, 2016a). The fast development of software and information and technology (IT) services, as well as the digitization of the economy, stimulates longand short-term value creation for different stakeholder groups (Sustainability Accounting Standards Board, 2014).

Publications of the Central Statistical Office of Poland demonstrate that, in 2016, the overall business conditions in Poland in the information and communications (I\&C) sector were improving. The sector involves enterprises offering software and IT consultancy services, which are analyzed in this paper. According to the assessments, in the case of $23.7 \%$ of companies in February 2016, the business climate had a positive impact, and business tendency for $6.5 \%$ of companies deteriorated, while for the remaining business entities, there were no noticeable changes in their financial situation (Central Statistical Office, 2016a). Labor costs had become the greatest barrier for doing business in the I\&C sector (affecting 50.2\% of companies in February 2016 and 54.9\% in February 2015). Since mid-2013, the importance of this barrier, which relates to the shortage of skilled employees, has risen (from $21.9 \%$ in February of the previous year to $25.1 \%$ in the corresponding month of 2016) (Central Statistical Office, 2016b). This may be one of the major causes for continuous mergers and acquisitions (M\&As) among Polish players offering software and IT consultancies, which contribute to developing products and services, reduction of costs (expenses), and the building of strong brands. Mergers and acquisitions help Polish companies increase or retain market share. Polish companies, in the analyzed sector, intensely compete with one another. Approximately $40 \%$ of companies have identified domestic competition as a significant barrier to business (Central Statistical Office, 2016b).

In 2013-2014, only $0.6 \%$ of all non-financial enterprises, surveyed by the Polish Central Statistical Office 2015), were enterprises that formed groups. However, these enterprises generated more than half of the revenue of non-financial enterprises (Central Statistical Office, 2015). Of all groups operating in Poland during 2014, companies of the Polish I\&C sector were ranked sixth and in terms of revenues from sales generated by non-financial companies, they were ranked fourth. Their net

\footnotetext{
${ }^{1}$ Jolanta Wartini-Twardowska, Faculty of Finance and Insurance, University of Economics in Katowice, Poland, j.wartini_twardowska@ue.katowice.pl

2 Zbigniew Twardowski, Faculty of Information and Communication Technology, Silesian Higher School of Economics, Katowice, Poland, CEO of s4Bi sp. z o.o., zbigniew.twardowski@s4bi.com.pl
} 
financial results were high and thus, they were ranked third among all non-financial groups. Similar to 2013, they also played a dominant role in generating total net income in 2014. (Central Statistical Office, 2015).

The view that the competitive advantage of organizations is achieved through unique applications of IT resources, which creatively solve business problems of organizations, is becoming increasingly widespread. Effective combining of business models within complex organizations (particularly in enterprise groups) makes it possible to develop a product offer for the customer. Owing to new business models of companies in the MIS sector, barriers to business can be overcome. In the dynamic, value-oriented approach to the strategic management of M\&As, considering intra- and intercompany relations in the business model approach is crucial. The authors applied this approach to accomplish the primary objective of this paper, i.e., to present the methodology of assessing opportunities and threats relating to combining businesses with heterogeneous business models. To attain this goal, the following specific questions were asked:

- What are typical business models in the Polish Management Information Systems sector?

- Which business models of the MIS sector are key, and which models are highly responsive to other models, or are highly independent?

- How does one approach the issue of building a unique structure for enterprise groups?

- What should be the stages of an in-depth analysis of the cross-impact exerted by key processes affecting group business models?

- What are the potential effects (risks) of combining two key business models, e.g., the IT integrator and the added value reseller, into an enterprise group?

In this paper, we propose a methodology for designing group business models that provide definitive answers to these posed questions.

The subject-matter of this paper aligns with studies carried out internationally in regards to business model concepts and how to use these to explain business complexity. In published works, such concepts were examined in terms of various connotations (Stähler, 2002; Wirtz, 2011), including technological (Konczal, 1975; Dottore, 1977; Stähler, 2002), organizational (Treacy \& Wiersema, 1997), and strategic (Normann \& Ramirez, 1993; Zott \& Amit, 2008; Casadesus-Masanell \& Ricart, 2010); by perspectives of economic, operational, and strategic (Morris, Schindehutte, Richardson, \& Allen, 2006), and in the domains of finance, service, technology, and organization (Bouwman, Faber, Haaker, \& de Reuver, 2008). Chatterjee and Brueller drew attention to M\&As that aim to build new business models with a new value proposition. These treat business combinations as potentially disruptive for a market (Chatterjee \& Brueller, 2015). Both business and customer values have been continuously emphasized and thus, these are central to business model variants (Shin \& Park, 2009). The literature on the subject, categorizes business model concepts in a scientific manner. This categorization comprises, for example, the ordering of business model components, proposed typologies, and also reference to the innovation of a business model and the management of business models (Chesbrough \& Rosenbloom, 2002; Markides, 2008; Chesbrough, 2010; Holloway \& Sebastiao, 2010; Sanchez \& Ricart, 2010; Teece, 2010; Cavalcante, Kesting, \& Ulhøi, 2011; Casadesus-Masanell \& Zhu, 2013; Wirtz, 2011; Osterwalder \& Pigneur, 2012; Sniukas, 2012; Wartini-Twardowska, 2014). While many innovative business models are created by start-up enterprises, there are also cases of established enterprises experimenting with new business models as a way of responding to the competitive threats from such start-ups (Birkinshaw \& Ansari, 2015).

\section{Research Methodology}

This study assessed risks relating to business combinations, particularly in designing the structure of groups, using a business model concept. As proposed by Wartini-Twardowska (2014), the business models of companies involved in M\&As were identified first (Figure 1).

Then, using a cross-impact method, including Vester's sensitivity model, an analysis of identified business models of the MIS sector was carried out (Vester \& Hesler, 1980). This assisted in classifying the models into four categories (Figure 3). 
Next, a two-stage in-depth analysis of the impact of key processes on other business models for a group was proposed (this is described later in this paper). The authors applied the 'process classification framework', developed by the American Productivity and Quality Center to identify the key operating processes of each model (APQC, 2015). The description of the models was based partially on Wartini-Twardowska (2014). The findings of the survey, which covered 250 typical business models of the Polish companies presented in the aforementioned publication, were used to characterize the operating processes in fifteen basic models of the MIS sector (Figure 1). Subsequent to this, experts in particular fields were consulted regarding the identified processes.

Figure 1: Typical business models of the management information systems sector

\begin{tabular}{|c|c|c|c|c|c|c|}
\hline \multirow{2}{*}{\multicolumn{2}{|c|}{$\begin{array}{r}\text { Sector's } \\
\text { value chain }\end{array}$}} & 1 & 2 & 3 & 4 & 5 \\
\hline & & Design & Production & Distribution & Imple mentation & $\begin{array}{c}\text { Maintenanc } \\
\mathbf{e}\end{array}$ \\
\hline 1 & $\begin{array}{l}\text { Customer } \\
\text { integration }\end{array}$ & $\begin{array}{l}1.1 \\
\text { Independent IT } \\
\text { Advisor (ADV) }\end{array}$ & \begin{tabular}{|l}
2.1 \\
Independent \\
Software \\
Vendor \\
(ISV)
\end{tabular} & \begin{tabular}{|l}
3.1 \\
Added Value \\
Reseller \\
$($ AVR)
\end{tabular} & $\begin{array}{l}4.1 \\
\text { Inte grator } \\
\text { (INT) }\end{array}$ & $\begin{array}{l}5.1 \\
\text { Help Desk } \\
(\text { HDK) }\end{array}$ \\
\hline 2 & $\begin{array}{l}\text { Effects of } \\
\text { economies of } \\
\text { scale and/or } \\
\text { experience } \\
\text { effect }\end{array}$ & $\begin{array}{l}1.2 \\
\text { IT Auditor } \\
(\text { AUD) }\end{array}$ & $\begin{array}{l}2.2 \\
\text { Software } \\
\text { Development } \\
\text { Company } \\
\text { (SDC) }\end{array}$ & $\begin{array}{l}3.2 \\
\text { Distributor (DIS) }\end{array}$ & $\begin{array}{l}4.2 \\
\text { Freelancer } \\
(\text { FRL })\end{array}$ & $\begin{array}{l}5.2 \\
\text { IT on Demand } \\
\text { (ITD) }\end{array}$ \\
\hline 3 & Innovations & \begin{tabular}{|l}
1.3 \\
IT Business \\
Consultant \\
$(\mathrm{BCS})$
\end{tabular} & $\begin{array}{l}2.3 \\
\text { IT Lab } \\
(\mathrm{LAB})\end{array}$ & $\begin{array}{l}3.3 \\
\text { Challenger } \\
(\mathrm{CHL})\end{array}$ & $\begin{array}{l}4.3 \\
\text { Software House } \\
(\mathrm{STH})\end{array}$ & $\begin{array}{l}5.3 \\
\text { Service } \\
\text { Provider (SPR) }\end{array}$ \\
\hline
\end{tabular}

Source: Wartini-Twardowska (2014)

\section{Typical Business Models of the MIS Sector}

The fifteen-field 'Wartini-Twardowska' matrix, which is constructed on two dimensions, i.e., the value chain of the sector with five elements and three basic competitive strategies, comprises fifteen MIS sector business models. A strategy for integrating a simultaneous focus on business solution design with the customer creates the conditions for developing a company in the form of a traditional 'IT advisor', where the greatest value for the customer consists in the competencies, availability, and objectivity of an advisor in formulating opinions (Model 1.1). In the case of the 'IT auditor' business model, focus is placed on the repeatability of the offered product (in particular for audit services). The greatest advantage of the model is the development and implementation of standards. ${ }^{3}$ The operating method of such a business entity is comparable to that of typical auditors that audit a company's assets, financial standing, and income, or to procedures ensuring continuity of an organization's operations (Model 1.2). In turn, an 'IT business consultant' is expected to improve management processes (Model 1.3).

Frequently, innovations in modelling the customer's business functions and processes affect the success of further implementation of the management information systems. In the case of organizations that focus mainly on developing their own IT product, a strategy of full integration with a customer allows favorable conditions to be created for developing very specific, independent software vendors (Model 2.1). However, the vision of an IT product as a market standard for a wide

\footnotetext{
${ }^{3}$ A typical example is a company implementing ITIL or ISO standards in information management security.
} 
range of applications substantially changes the software development company's perception of the success of such an undertaking (Model 2.2). 'IT labs' are organizations focused mainly on product innovations. They include companies that are often connected with scientific units or that constitute research and development (R\&D) for large IT corporations (Model 2.3).

The value chain element, responsible for product or service distribution (delivery), or both, relates to business models that have distinctly vague (fuzzy) characteristics. An 'added value reseller' creates value during distribution of solutions for end users. This model delivers value mainly by adapting an existing product in the market to specific customer needs (Model 3.1.). In turn, a 'distributor' is a model of a unit that focuses on providing services, mainly about delivery, for the largest possible number of customers. It offers standard products to end users and components for the construction of final IT solutions. The classic distributor focuses mainly on logistics (Model 3.2). In the 'challenger' business model, delivery includes pioneering technologies on the market for management system solutions, which also exploit opportunities for IT in new areas of organizational management. To avoid losing liquidity, a company that chooses to use technology needs to focus primarily on managing the risks associated with implementing the project portfolio. Where some projects fail, the company's financial liquidity may be jeopardized (Model 3.3).

In the MIS sector, implementing an IT solution plays a critical role in creating value for the customer. Thus, the fourth group of models comprises companies that focus on capturing value during implementation. An 'integrator' is a business model of an organization that specializes in comprehensive implementation of IT solutions for specific customer needs (Model 4.1). The 'integrator' usually supervises the implementation of delivery at the customer's premises (managing an implementation project). A 'freelancer' is a company (often a real person) that creates value through fast implementation of an existing standard and by adjusting the organization's management processes to the requirements of the management system being implemented (Model 4.2.). The last model in the group is focused on solving a customer's non-typical business problems, related to current IT services. A typical 'software house' comprises first-rate programmers and IT designers who undertake 'turn-key' programming assignments for other IT solution suppliers (Model 4.3).

Given the changes in the model of purchase and use of IT solutions, the last element of the value chain (maintenance) plays an increasingly significant role in value creation for the customer in the MIS sector. Companies focused on full integration with the customer develop a classic 'help desk' model that constitutes the first line of customer support (Model 5.1) within the framework of support for IT infrastructure and software maintenance. Companies increasingly tend to outsource IT processes, including all data processing and a significant part of business software. In the case of the 'IT on demand' business model, a business entity focuses on data processing services, and lease and maintenance of business software for the customer (Model 5.2). The last model considered in this categorization is that of a company that specializes in advanced maintenance services and in solving non-typical customer problems (the second and third line of maintenance support; Model 5.3).

\section{Value Creation in the MIS Sector and Intra-Corporate Relationships}

The quest for a strategic advantage by improving the structure of resources and competences in a few links of the value chain leads to an organization focusing on more than one typical business model in the sector. Thus, each company creates its own original business architecture, comprising the suggested combination of basic models (in extreme cases, the organization may successfully operate using one of the business models presented in Figure 1).

Within this architecture, the competitive ability of an enterprise group is built with both a unique structure of models in the group and the combination of relations between models. Thus, the complexity of a group's business architecture is directly proportional to the number of heterogeneous business models operated by the subsidiaries. Identifying key processes to create the added value of such a group calls for determining the strength and effects of interactions through a given business model embedded in the environment of other models. For this purpose, the authors applied the crossimpact method to examine the traits of typical business models of the MIS sector essentially from the point of view of creating interactions (Figure 2). 
Figure 2: Potential cooperation links in the process of creating value for the customer

\begin{tabular}{|c|c|c|c|c|c|c|c|c|c|c|c|c|c|c|c|c|}
\hline & 1.1 & 1.2 & 1.3 & 2.1 & 2.2 & 2.3 & 3.1 & 3.2 & 3.3 & 4.1 & 4.2 & 4.3 & 5.1 & 5.2 & 5.3 & $\overline{\mathbf{A S}}$ \\
\hline 1.1 & $\cdot$ & 1 & 2 & 2 & 1 & 1 & 2 & 0 & 2 & 2 & 0 & 0 & 1 & 1 & 1 & 16 \\
\hline 1.2 & 0 & • & 1 & 1 & 0 & 0 & 1 & 0 & 1 & 0 & 0 & 0 & 0 & 0 & 0 & 4 \\
\hline 1.3 & 0 & 0 & $\bullet$ & 2 & 0 & 1 & 2 & 0 & 1 & 2 & 0 & 1 & 0 & 0 & 0 & 9 \\
\hline 2.1 & 0 & 0 & 1 & $\bullet$ & 1 & 1 & 2 & 2 & 0 & 2 & 1 & 0 & 0 & 1 & 1 & 12 \\
\hline 2.2 & 0 & 0 & 1 & 1 & • & 1 & 2 & 3 & 1 & 2 & 1 & 1 & 0 & 2 & 1 & 16 \\
\hline 2.3 & 0 & 0 & 0 & 0 & 1 & • & 0 & 0 & 3 & 1 & 0 & 0 & 0 & 0 & 0 & 5 \\
\hline 3.1 & 0 & 0 & 1 & 0 & 0 & 0 & • & 0 & 0 & 3 & 0 & 1 & 0 & 0 & 0 & 5 \\
\hline 3.2 & 0 & 0 & 1 & 1 & 1 & 0 & 3 & $\bullet$ & 1 & 3 & 0 & 1 & 0 & 1 & 2 & 14 \\
\hline 3.3 & 0 & 0 & 0 & 0 & 0 & 0 & 0 & 0 & $\bullet$ & 1 & 0 & 0 & 0 & 0 & 0 & 1 \\
\hline 4.1 & 0 & 0 & 1 & 0 & 0 & 0 & 1 & 0 & 0 & $\cdot$ & 0 & 0 & 0 & 0 & 0 & 2 \\
\hline 4.2 & 0 & 0 & 1 & 2 & 1 & 1 & 2 & 0 & 0 & 3 & - & 1 & 0 & 0 & 2 & 13 \\
\hline 4.3 & 0 & 0 & 0 & 1 & 0 & 1 & 1 & 0 & 0 & 2 & 0 & $\cdot$ & 0 & 0 & 1 & 6 \\
\hline 5.1 & 0 & 0 & 1 & 2 & 2 & 1 & 3 & 0 & 1 & 3 & 0 & 1 & $\bullet$ & 0 & 2 & 16 \\
\hline 5.2 & 0 & 0 & 0 & 0 & 1 & 0 & 2 & 0 & 0 & 2 & 0 & 0 & 0 & $\bullet$ & 0 & 5 \\
\hline 5.3 & 0 & 0 & 0 & 1 & 1 & 0 & 1 & 0 & 0 & 2 & 0 & 1 & 0 & 1 & • & 7 \\
\hline PS & $\mathbf{0}$ & 1 & 10 & 13 & 9 & 7 & 22 & 5 & 10 & 28 & 2 & 7 & 1 & 6 & 10 & \\
\hline
\end{tabular}

Source: Authors

For example, an 'independent IT advisor' (Model 1.1) has a large impact on other models because of likely suggestions concerning the end user's selection of a business partner (Figure 3). At the same time, because of the model's independence, no other models may be involved. Thus, in the crossimpact matrix, the 'independent IT advisor' model has a high active sum and a zero passive sum. In turn, the 'integrator' (Model 4.1), which provides value directly to the end user, uses services of most of the identified business models in the sector. Therefore, the active sum for this model is quite small, while the passive sum is relatively high. The 'auditor' (Model 1.2) and 'IT on demand' (Model 5.2) operate differently again. These models are characterized by a relatively small active and passive sums. The criteria of active and passive sums allow the business models to be classified into four categories: active, critical, passive, and inert models.

Figure 3: Results of an analysis of the cross-impact of fifteen typical business models (1.1 to 5.3) of the Polish management information system sector

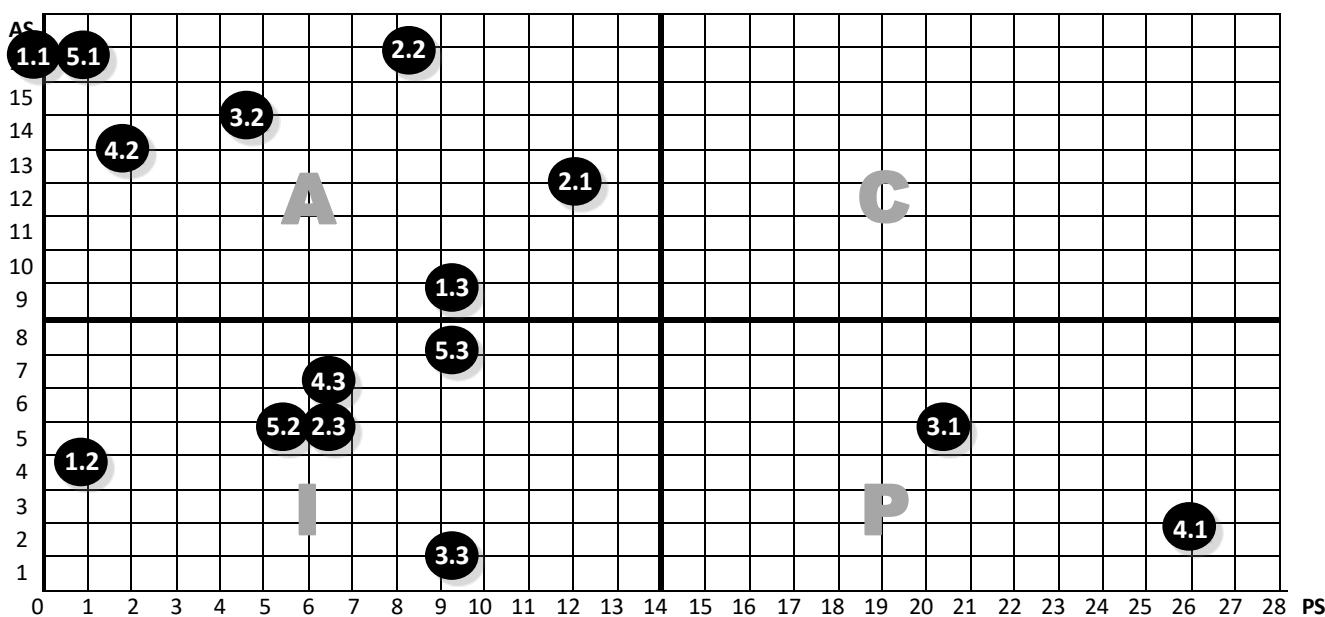

A: active models; C: critical models; P: passive models; I: inert models

\section{Source: Authors}

Group A of the active models have high active sums and small passive sums. These models, by having a significant impact on customer value, have a powerful influence on other business models. In the case under consideration, this group comprised seven business models that represented all elements of the MIS sector value chain (Figure 3). 
The other group (Group P) comprised models characterized by a high passive but small active sum. Models in this group were strongly influenced by other models on which they had a small, but direct impact. These were models, therefore, that strongly reacted to the consequences of other operating models. They could become a unique measure for the state of a group (and even of the whole sector, as they give early information about the direction of changes in trends within a sector). Two models performed such functions: the 'integrator' (INT; Model 4.1) and the 'added value reseller' (AVR; Model 3.1). Both were strongly focused on integration with the customer, and this highlighted their position as leaders in the value creating system.

The last group of models (Group I), which in this case comprised six representatives, was characterized by relatively small passive and active sums. These are the so-called buffer (or inert) models whose major advantage was their large degree of independence. They were negligibly sensitive to the influence of other models, on which they also had a small impact.

Based on further in-depth analysis of cross-impacts between MIS sector models, the following conclusions were drawn. Firstly, the key models in the MIS sector were the IT software and infrastructure producers; this resulted from their active position in the map with the highest coefficients of active sum cross-matched with passive sum (for example, the coefficient for model 2.2 was 114; i.e., $16 \times 9$ ). These models, which are supported by other active models, established foundations for the value of the sector. Secondly, the most important 'providers' of customer value were 'integrators' and 'added value resellers'. The customer, in the end, perceives the offered value from the angle of broadly understanding the product's usefulness. In the case of solutions for management support, this is often connected with intricate implementation. The 'added value of the reseller' or 'integrator' provides the customer with all necessary components and services so that the customer achieves the goal intended with buying the IT software or infrastructure. Furthermore, through observation of the financial standing of resellers and integrators, given their functions in the value chain, a system can be created that allows for early identification of opportunities and threats for the whole sector. Thirdly, where the activity is focused on initiating (economic or legal) business combinations, positioning of a potential subsidiary in the active sum against the passive sum map allows for early identification of opportunities and threats during M\&A planning. The MIS sector, which is subject to continuous changes, would enable the companies to: 1) revise the sector map, and 2) position themselves better on the sector map by using the identified opportunities.

\section{Analysis of the Cross-Impact of Key Processes of Heterogeneous Business Models in an Enterprise Group}

Assessment of the contribution of a particular business model to the creation of a group's value must be preceded by an in-depth analysis of the impact of key processes of the analyzed model on other models in the group. The authors conducted the analysis in two stages.

Stage 1: Classification of Business Processes

The structure of classifying business processes included in Table 1 was based on the 'process classification framework', developed by the American productivity and quality center. The importance of individual processes for each business model was determined on a four-point scale, based on the impact of the process upon the customer value proposition. The maximum number of points, i.e., four, marked $(\bullet \bullet \bullet \bullet$ or $\bigcirc \circ \circ \circ)$ was given to the processes critical for the value proposition. The minimum score, indicated by a single point $(\bullet$ or $\circ)$, denoted marginal impact. For example, in the case of the FRL model, the operating processes in the fourth category (i.e., 4.0 Deliver Products and Services), were the only processes that created customer value. In the case of the SDC model, the processes crucial for the creation of the final customer value proposition were those responsible for developing vision and strategy (1.0 Develop Vision and Strategy) and covering sale and marketing (2.0 Develop and Manage Products and Services; or 4.0 Deliver Products and Services).

Subsequently, particular groups of processes assigned to each category were assessed in terms of their importance, using the same marking scale. Hence, for the FRL model, which was analyzed previously, the processes responsible for implementing IT solutions (4.4 Deliver Service to Customer) constituted the key group and, in the case of the SDC model, in the fourth category: Deliver Products and Services (10005), the group of processes covering software production (4.3, Produce/Manufacture/Deliver Products) determined the attractiveness of the customer value proposition. 


\section{Stage 2: Analysis of the Cross-Impact of Key Processes on Value Propositions of a Group}

In the second stage of the study, the authors analyzed the selected business models for the impact of the key processes of one model on the value proposition of another. For this purpose, the process groups identified in the first stage of the study were divided into processes and sub-processes (activities) creating the customer value proposition for each business model.

Table 1: Operating process groups of typical business models of the MIS sector

\begin{tabular}{|c|c|c|c|c|c|c|c|c|c|c|c|c|c|c|c|c|}
\hline No. & Ope rating Processes Groups & & & & & & & Busin & ess M & odels & & & & & & \\
\hline & & ADV & AUD & BCS & ISV & SDC & LAB & \begin{tabular}{|c|}
$\mathbf{A V}$ \\
$\mathbf{R}$
\end{tabular} & DIS & CHL & INT & FRL & STH & HDC & ITD & SPR \\
\hline 1.0 & $\begin{array}{l}\text { Develop Vision and Strategy } \\
(10002)\end{array}$ & $\bullet$ & $\bullet \bullet$ & $\bullet \bullet \bullet$ & $\bullet \bullet$ & $\bullet \bullet \bullet$ & $\bullet \bullet$ & $\bullet \bullet$ & $\bullet$ & $\bullet \bullet$ & $\bullet \bullet \bullet$ & $\bullet$ & $\bullet \bullet$ & $\bullet$ & $\bullet \bullet \bullet$ & $\bullet \bullet$ \\
\hline 1.1 & $\begin{array}{l}\text { Define the business concept and } \\
\text { long-term vision }\end{array}$ & - & ০ & ০ & o & $0 \circ 0$ & ০০ & ○ & ○ & ०० & 000 & - & ○ & $\circ$ & 000 & ○ \\
\hline 1.2 & Develop business strategy & & $\circ$ & ০০০ & ০ & $\begin{array}{l}\circ \\
\circ \circ\end{array}$ & ○ & $\circ$ & ० & ०० & 000 & $\circ$ & ০ & o & 000 & ० \\
\hline 1.3 & Manage strategic initiatives & - & $\circ$ & ०० & $\circ$ & ०० & ○ & ○ & ○ & ○ & ○ & - & ○ & - & o & ০० \\
\hline 2.0 & $\begin{array}{l}\text { Develop and Manage Products } \\
\text { and Services }(\mathbf{1 0 0 0 3 )}\end{array}$ & $\bullet$ & $\bullet$ & $\bullet \bullet$ & $\bullet$ & $\bullet \bullet \bullet$ & $\begin{array}{ll}\bullet \bullet \\
\bullet \bullet\end{array}$ & $\bullet$ & $\bullet \bullet \bullet$ & $\bullet \bullet$ & $\bullet \bullet$ & $\bullet$ & $\bullet \bullet$ & $\bullet$ & $\bullet \bullet$ & $\bullet \bullet \bullet$ \\
\hline 2.1 & $\begin{array}{l}\text { Manage product and service } \\
\text { portfolio }\end{array}$ & - & $\circ$ & $\circ$ & o & ००० & $\circ$ & $\circ$ & 000 & ○ & ০০০ & - & ০ & $\circ$ & $\circ$ & ○ \\
\hline 2.2 & Develop products and services & $\circ$ & $\circ$ & ০ & ০ & ००० & $\begin{array}{l}\circ \\
\circ \circ\end{array}$ & ০০ & ○ & ০০ & $\circ$ & ०० & ০ & $\circ$ & ०० & $\circ \circ 0$ \\
\hline 3.0 & $\begin{array}{l}\text { Market and Sell Products and } \\
\text { Services (10004) }\end{array}$ & $\bullet$ & $\bullet \bullet$ & $\bullet \bullet$ & $\bullet \bullet \bullet$ & $\bullet \bullet$ & $\bullet$ & $\bullet \bullet \bullet$ & $\stackrel{\bullet}{\bullet \bullet}$ & $\begin{array}{ll}\bullet \\
\bullet \bullet\end{array}$ & $\bullet \bullet \bullet$ & $\bullet$ & $\bullet \bullet \bullet$ & $\bullet \bullet$ & $\bullet \bullet$ & $\bullet \bullet$ \\
\hline 3.1 & $\begin{array}{l}\text { Understand markets, customers } \\
\text { and capabilities }\end{array}$ & $\circ$ & ০০ & $\begin{array}{l}\circ \\
\circ \circ\end{array}$ & 000 & ०० & 0000 & ০০ & 000 & 0000 & 000 & $\circ$ & $0 \circ 0$ & o & ০० & $0 \circ 0$ \\
\hline 3.2 & Develop marketing strategy & ○ & ०० & ০० & ০ & $0 \circ 0$ & $\circ$ & ○ & ০ & 000 & ০ & $\circ$ & ০ & ० & ००० & ০ \\
\hline 3.3 & Develop sales strategy & - & $\circ$ & $\circ$ & 000 & $\begin{array}{l}\circ \\
\circ \circ\end{array}$ & $\circ$ & ○ & $\begin{array}{l}\circ \\
\circ \circ\end{array}$ & ০০ & ০ & - & ০ & $\circ$ & $\begin{array}{l}\circ \circ \\
\circ \circ\end{array}$ & ○ \\
\hline 3.4 & $\begin{array}{l}\text { Develop and manage marketing } \\
\text { plans }\end{array}$ & - & $\circ$ & ○ & ০ & ० & $\circ$ & ○ & ০ & ০০ & $\circ \circ$ & $\circ$ & ০ & ○০ & ০ & ○ \\
\hline 3.5 & Develop and manage sales plans & - & $\circ$ & $\circ$ & ০ & $\begin{array}{ll}00 \\
0 \circ\end{array}$ & ०० & $\circ \circ \circ$ & $\begin{array}{l}\circ \\
\circ \circ\end{array}$ & ०० & 000 & $\circ$ & $\circ \circ$ & $\circ$ & $\begin{array}{l}\circ \\
\circ \circ\end{array}$ & 000 \\
\hline 4.0 & $\begin{array}{l}\text { Deliver Products } \\
\text { and Services (10005) }\end{array}$ & $\bullet \bullet \bullet$ & $\bullet \bullet$ & $\begin{array}{ll}\bullet \\
\bullet \bullet\end{array}$ & $\bullet \bullet \bullet$ & $\bullet \bullet \bullet$ & $\bullet \bullet \bullet$ & $\bullet \bullet$ & $\bullet \bullet \bullet$ & $\bullet \bullet \bullet$ & $\bullet \bullet \bullet$ & $\begin{array}{ll}\bullet \\
\bullet \bullet\end{array}$ & $\bullet \bullet \bullet$ & $\bullet \bullet$ & $\bullet$ & $\bullet \bullet \bullet$ \\
\hline 4.1 & $\begin{array}{l}\text { Plan for and align supply chain } \\
\text { resources }\end{array}$ & - & - & - & $\circ$ & ०० & $\circ$ & ○ & - & $\circ$ & 000 & - & $\circ$ & - & - & ○ \\
\hline 4.2 & $\begin{array}{l}\text { Procure materials } \\
\text { and services }\end{array}$ & - & - & - & ० & $\circ$ & ○ & $\circ$ & - & $\circ$ & ০ & - & $\circ$ & - & o & 000 \\
\hline 4.3 & $\begin{array}{l}\text { Produce/Manufacture/Deliver } \\
\text { products }\end{array}$ & - & - & ○ & 000 & $\begin{array}{l}\circ \circ \\
\circ \circ\end{array}$ & $\begin{array}{l}\circ \circ \\
\circ \circ\end{array}$ & $0 \circ 0$ & $\begin{array}{l}\circ \circ \\
\circ \circ\end{array}$ & $\begin{array}{l}\circ \\
\circ \circ\end{array}$ & ○ & - & 000 & - & - & - \\
\hline 4.4 & $\begin{array}{l}\text { Deliver service } \\
\text { to customer }\end{array}$ & $\begin{array}{ll}\circ \\
0 \circ\end{array}$ & $\begin{array}{ll}0 \\
00\end{array}$ & $\begin{array}{l}\circ \\
\circ \circ\end{array}$ & ০० & o & o & 00 & o & 00 & $\begin{array}{l}\circ \circ \\
\circ \circ\end{array}$ & $\begin{array}{l}\circ \circ \\
\circ \circ\end{array}$ & ०० & $\begin{array}{l}0 \\
\circ \circ \\
\end{array}$ & $\begin{array}{l}\circ \\
\circ \circ \\
\end{array}$ & $\begin{array}{l}0 \\
\circ \circ\end{array}$ \\
\hline 4.5 & $\begin{array}{l}\text { Manage logistics and } \\
\text { warehousing }\end{array}$ & - & - & - & - & ○ & - & ○ & 000 & ○ & ०० & - & o & - & - & ०० \\
\hline 5.0 & $\begin{array}{l}\text { Manage Customer Service } \\
(\mathbf{1 0 0 0 6 )}\end{array}$ & $\bullet \bullet$ & • & $\bullet$ & $\bullet \bullet$ & • & $\bullet$ & $\bullet \bullet \bullet$ & $\bullet$ & • & $\bullet$ & $\bullet \bullet$ & $\bullet \bullet$ & $\bullet \bullet$ & $\bullet \bullet$ & $\begin{array}{ll}\bullet \bullet \\
\bullet \bullet\end{array}$ \\
\hline 5.1 & $\begin{array}{l}\text { Develop customer care/customer } \\
\text { service strategy }\end{array}$ & - & - & o & ০० & 000 & ○ & o & - & o & ०० & - & o & 00 & - & 000 \\
\hline 5.2 & $\begin{array}{l}\text { Plan and manage customer } \\
\text { service operations }\end{array}$ & & - & o & 000 & ○ & ○ & 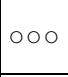 & - & ०० & 000 & - & 000 & $\begin{array}{l}0 \circ \\
\circ \circ \\
\end{array}$ & ○ & $\begin{array}{l}0 \circ \\
\circ \circ \\
\end{array}$ \\
\hline 5.3 & $\begin{array}{l}\text { Measure and evaluate customer } \\
\text { service operations }\end{array}$ & - & - & ○ & 000 & 000 & ○ & 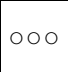 & - & $\begin{array}{l}0 \circ \\
\circ \circ\end{array}$ & ०० & - & ०० & 00 & o & 000 \\
\hline
\end{tabular}

$\bullet \bullet \bullet \bullet$ - crucial impact of the processes on the value proposition; $\bullet \bullet \bullet-$ strong impact of the processes; $\bullet \bullet-$ significant impact of the processes; $\bullet$ - marginal impact of the processes; - no impact of the processes; $০ \circ ০ \bigcirc$ - crucial impact of the sub-processes on the value proposition; ০০০ - strong impact of the sub-processes; ○০ - significant impact of the sub-processes; $\bigcirc-$ marginal impact of the sub-processes

Source: Authors 
The authors used two examples of business models, i.e., the INT and AVR, in the in-depth analysis of the cross-impact of key processes. The analysis comprised the following phases: (1) defining strategic objectives of companies operating in the AVR and INT models listed in Table 2; (2) analyzing the impact of key processes of one model on the strategic objectives of another; and (3) assessing opportunities and threats relating to combined models within an enterprise group.

Selected Strategic Objectives of the AVR and the INT Models

The INT and AVR models had the same four objectives: (1) focus on market share growth resulting from the acquisition of new customers and strengthening of ties with existing customers; (2) improve operating processes, which were expressed by the above-average profitability of implemented projects; (3) focus development primarily on improved competences of human resources; and (4) maintain financial results expressed by metrics that measure the risk associated with short- and longterm financial liquidity.

Table 2: Groups of business objectives affecting the added value growth in integrator (INT) and the added value reseller (AVR) models

\begin{tabular}{|c|c|c|c|}
\hline No. & Primary objectives & No. & Sub-objectives \\
\hline \multirow{3}{*}{1.} & \multirow{3}{*}{$\begin{array}{l}\text { Market development } \\
\text { (market share growth) }\end{array}$} & 1.1. & $\begin{array}{l}\text { An increase in the number of new customers } \\
\text { in serviced sectors }\end{array}$ \\
\hline & & 1.2. & $\begin{array}{l}\text { An increase in the revenue from technical support services } \\
\text { provided to existing customers }\end{array}$ \\
\hline & & 1.3. & $\begin{array}{l}\text { An increase in the revenue from the sale of new services to } \\
\text { existing customers (upsells, aftermarket) }\end{array}$ \\
\hline \multirow{3}{*}{2.} & \multirow{3}{*}{$\begin{array}{l}\text { An increase } \\
\text { in/maintenance } \\
\text { of the above-average } \\
\text { profitability } \\
\text { of provided services }\end{array}$} & 2.1. & Improving deployment projects management \\
\hline & & 2.2. & $\begin{array}{l}\text { Augmenting the bargaining position against the main } \\
\text { vendors }\end{array}$ \\
\hline & & 2.3. & $\begin{array}{l}\text { Using the operating leverage in the development } \\
\text { of the operating costs structure }\end{array}$ \\
\hline \multirow{3}{*}{3.} & \multirow{3}{*}{$\begin{array}{l}\text { The development } \\
\text { of employee } \\
\text { competences } \\
\text { and qualifications }\end{array}$} & 3.1. & Improving the competences of deployment teams \\
\hline & & 3.2. & $\begin{array}{l}\text { Standardization and/or automation of deployment } \\
\text { procedures }\end{array}$ \\
\hline & & 3.3 & Developing corporate knowledge bases \\
\hline \multirow[t]{2}{*}{4.} & \multirow{2}{*}{$\begin{array}{l}\text { Maintaining the safe } \\
\text { structure } \\
\text { of operations financing }\end{array}$} & 4.1. & $\begin{array}{l}\text { Determining the level and structure of working capital } \\
\text { which reduces the risk of financing deployment projects }\end{array}$ \\
\hline & & 4.2. & $\begin{array}{l}\text { Using financial leverage in the development } \\
\text { of the long-term equity and assets structure }\end{array}$ \\
\hline
\end{tabular}




\section{Perspective on the Objectives of the AVR Model}

By examining the accomplishment of strategic objectives for the AVR model from the point of view of the processes of the INT model (Table 3), one can claim that those involving the delivery of products and services (10005), as part of the complex deployment projects of the INT, constituted the greatest added value. The processes of this group (Deliver Products and Services) primarily supported the AVR objectives relating to the operating profitability of projects, and to a smaller degree, supported the market-related and financial AVR objectives.

Table 3: Operating processes groups of the integrator (INT) model supporting added value reseller (AVR) objectives

\begin{tabular}{|c|c|c|c|c|c|c|}
\hline \multirow{2}{*}{ No. } & \multirow{2}{*}{\multicolumn{2}{|c|}{ Operating Processes Groups of INT }} & \multicolumn{4}{|c|}{ AVR objectives } \\
\hline & & & \multirow{2}{*}{$\begin{array}{l}\text { I } \\
\bullet\end{array}$} & \multirow{2}{*}{$\begin{array}{l}\text { II } \\
\bullet\end{array}$} & \multirow{2}{*}{$\begin{array}{c}\text { III } \\
-\end{array}$} & \multirow{2}{*}{$\begin{array}{c}\text { IV } \\
-\end{array}$} \\
\hline 1.0. & 10002 & Develop Vision and Strategy & & & & \\
\hline 2.0 . & 10003 & Develop and Manage Products and Services & $\bullet \bullet$ & $\bullet \bullet$ & $\bullet$ & - \\
\hline 3.0. & 10004 & Market and Sell Products and Services & $\bullet \bullet$ & $\bullet \bullet$ & $\bullet$ & $\bullet$ \\
\hline 4.0. & 10005 & Deliver Products and Services & $\bullet \bullet$ & $\bullet \bullet$ & $\bullet$ & $\bullet \bullet$ \\
\hline 5.0 . & 10006 & Manage Customer Service & $\bullet \bullet$ & $\bullet \bullet \bullet$ & $\bullet$ & $\bullet$ \\
\hline \multicolumn{7}{|c|}{$\begin{array}{l}\bullet \bullet \bullet \bullet-\text { crucial impact of the INT processes on the AVR objectives; } \bullet \bullet \bullet-\text { strong impact of the INT } \\
\text { processes on the AVR objectives; } \bullet \bullet-\text { signi ficant impact of the INT processes on the AVR objectives; } \bullet- \\
\text { marginal impact of the INT processes on the AVR objectives; }- \text { no impact of the INT processes on the AVR } \\
\text { objectives }\end{array}$} \\
\hline
\end{tabular}

The INT processes, relating to market development, primarily supported the market-related objectives of the AVR model.

Develop Vision and Strategy

In this group of processes, support for the AVR objectives was relatively small, as shown in Table 4. However, depending on the definition of key market segments and the approach to the customer service method, the processes relating to developing competitive strategies could support or prevent mutual accomplishment of strategic objectives.

Table 4: Develop, vision, and strategy of integrator (INT) model supporting added value reseller (AVR) objectives

\begin{tabular}{|c|c|c|c|c|c|c|}
\hline \multirow{2}{*}{ No. } & \multirow{2}{*}{\multicolumn{2}{|c|}{ Develop Vision and Strategy of INT }} & \multicolumn{4}{|c|}{ AVR objectives } \\
\hline & & & \multirow{2}{*}{$\begin{array}{l}\text { I } \\
\bullet\end{array}$} & \multirow{2}{*}{$\begin{array}{l}\text { II } \\
\bullet\end{array}$} & \multirow{2}{*}{$\frac{\text { III }}{-}$} & \multirow{2}{*}{$\frac{\text { IV }}{-}$} \\
\hline 1.0 . & 10002 & Develop Vision and Strategy & & & & \\
\hline \multirow{2}{*}{1.1 . } & \multirow{2}{*}{$\begin{array}{l}\text { Define the } \\
\text { business } \\
\text { concept }\end{array}$} & - Assess the external environment (10017) & o & - & - & - \\
\hline & & $\begin{array}{l}\text { - Survey market and determine customer needs } \\
(10018)\end{array}$ & 0 & 0 & - & - \\
\hline \multirow{2}{*}{1.2.} & \multirow{2}{*}{$\begin{array}{l}\text { Develop } \\
\text { business } \\
\text { strategy }\end{array}$} & $\begin{array}{l}\text { - Evaluate strategic options to achieve the } \\
\text { obiectives (10038) }\end{array}$ & - & - & - & - \\
\hline & & - Select long-term business strategy (10039) & ० & - & - & - \\
\hline \multicolumn{7}{|c|}{$\begin{array}{l}\text { - marginal impact of the INT processes on the AVR objectives; - no impact of the INT processes (sub- } \\
\text { processes) on the AVR objectives; } \odot-\text { marginal impact of the INT sub-processes on the AVR objectives }\end{array}$} \\
\hline
\end{tabular}

Develop and Manage Products and Services

The last two groups for the INT processes supported the strategic objectives of the AVR model to a small extent only, as shown in Table 5. Processes that should be highlighted here are those that 
supported the designing of new services (10080) and managing the life cycles of products and services (10067).

Table 5: Develop and manage products and services of the integrator (INT) model supporting added value reseller (AVR) objectives

\begin{tabular}{|c|c|c|c|c|c|c|}
\hline \multirow{3}{*}{\begin{tabular}{|l} 
No. \\
2.0.
\end{tabular}} & \multirow{2}{*}{\multicolumn{2}{|c|}{$\begin{array}{l}\text { Develop and Manage Products and Services } \\
\text { of INT }\end{array}$}} & \multicolumn{4}{|c|}{ AVR objectives } \\
\hline & & & \multirow{2}{*}{$\begin{array}{l}\text { I } \\
\bullet \bullet\end{array}$} & \multirow{2}{*}{ II } & \multirow{2}{*}{ III } & \multirow{2}{*}{$\begin{array}{l}\text { IV } \\
-\end{array}$} \\
\hline & 10003 & $\begin{array}{l}\text { Develop and Manage Products } \\
\text { and Services }\end{array}$ & & & & \\
\hline \multirow{3}{*}{2.1.} & \multirow{3}{*}{$\begin{array}{l}\text { Manage product } \\
\text { and service } \\
\text { portfolio }\end{array}$} & $\begin{array}{l}\text { - Evaluate performance of existing products/services } \\
\text { (10063) }\end{array}$ & O & O & - & - \\
\hline & & - Define product/service development requirements (10064) & O & O & ०० & - \\
\hline & & - Manage product and service life cycle (10067) & ○ & ०० & - & - \\
\hline \multirow{2}{*}{2.2} & \multirow{2}{*}{$\begin{array}{l}\text { Develop products } \\
\text { and services }\end{array}$} & - Design, build, and evaluate products and services (10080) & ০० & O & 0 & - \\
\hline & & - Prepare for production (10082) & - & ०० & 0 & - \\
\hline
\end{tabular}

$\bullet \bullet-$ significant impact of the INT processes on the AVR objectives; $\bullet$ - marginal impact of the INT processes on the AVR objectives; - no impact of the INT processes (sub-processes) on the AVR objectives; o - significant impact of the INT sub-processes on the AVR objectives; O - marginal impact of the INT sub-processes on the AVR objectives

Source: Authors

Market and Sell Products and Services

The third group for the INT processes affected the accomplishment of strategic objectives for the AVR model and comprised processes that associated with broadly-understood marketing and sales strategies (Table 6). These were crucial for developing the AVR's market, particularly in acquiring new customers.

Table 6: Market and sell products and services of the integrator (INT) model supporting added value reseller (AVR) objectives

\begin{tabular}{|c|c|c|c|c|c|c|}
\hline \multirow{3}{*}{\begin{tabular}{|l|} 
No. \\
3.0.
\end{tabular}} & \multirow{2}{*}{\multicolumn{2}{|c|}{ Market and Sell Products and Services of INT }} & \multicolumn{4}{|c|}{ AVR objectives } \\
\hline & & & \multirow{2}{*}{$\begin{array}{l}\text { I } \\
\bullet \bullet \\
\bullet \bullet\end{array}$} & \multirow{2}{*}{ II } & \multirow{2}{*}{ III } & \multirow{2}{*}{ IV } \\
\hline & 10004 & Market and Sell Products and Services & & & & \\
\hline \multirow{2}{*}{3.1.} & \multirow{2}{*}{$\begin{array}{l}\text { Understand markets, } \\
\text { customers, and } \\
\text { capabilities }\end{array}$} & $\begin{array}{l}\text { - Perform customer and market intelligence analysis } \\
(10106)\end{array}$ & ০ & - & - & ○ \\
\hline & & - Evaluate and prioritize market opportunities (10107) & ০ & - & - & $\circ$ \\
\hline \multirow{2}{*}{3.2} & \multirow{2}{*}{$\begin{array}{l}\text { Develop marketing } \\
\text { strategy }\end{array}$} & $\begin{array}{l}\text { Define offering and customer value proposition } \\
\text { (11168) }\end{array}$ & ০ & - & - & - \\
\hline & & $\begin{array}{l}\text { - Define pricing strategy to align } \\
\text { to value proposition (10123) }\end{array}$ & 0 & ০ & - & ○ \\
\hline \multirow{2}{*}{3.3} & \multirow{2}{*}{$\begin{array}{l}\text { Develop sales } \\
\text { strategy }\end{array}$} & - Develop sales partner/alliance relationships (10130) & ০০০ & ০ & ० & ○ \\
\hline & & - Develop and manage sales plans (10105) & ০ & - & - & - \\
\hline \multirow{3}{*}{3.5} & \multirow{3}{*}{$\begin{array}{l}\text { Develop and manage } \\
\text { sales plans }\end{array}$} & - Generate leads (10182) & ০০ & - & - & - \\
\hline & & - Manage customer sales (10184) & $\begin{array}{l}\circ \\
\circ \circ\end{array}$ & - & - & - \\
\hline & & - Manage sales force (10186) & ০০০ & - & - & - \\
\hline \multicolumn{7}{|c|}{$\begin{array}{l}\bullet \bullet \bullet \bullet-\text { crucial impact of the INT processes on the AVR objectives; } \bullet \bullet-\text { significant impact of the INT processes on the } \\
\text { AVR objectives; } \bullet-\text { marginal impact of the INT processes on the AVR objectives; ○०००-crucial impact of the INT sub- } \\
\text { processes on the AVR objectives; ○०० - strong impact of the INT sub-processes on the AVR objectives; ○० - significant } \\
\text { impact of the INT sub-processes on the AVR objectives; ○-marginal impact of the INT sub-processes on the AVR } \\
\text { objectives; - no impact of the INT sub-processes on the AVR objectives }\end{array}$} \\
\hline
\end{tabular}


In an extreme case, a large INT may become the main distribution channel for an AVR's offer. The attractiveness of a product or service in accomplishing the objectives for the INT's strategic business will affect the success of this solution (from the AVR's point of view) and hence, the potential importance of the marketing and sales strategies of the INT for developing the AVR's market. Assuming the convergence of the INT's strategy with the AVR's value proposition, three INT processes will become crucial for developing the AVR's market, i.e., obtaining leads, sales process management, and sales teams management. The objectives relating to the profitability of the AVR's projects were supported by the INT's pricing policy and the selection of partners for the completion of deployment projects (10130).

Deliver Products and Services

In the first case, the AVR capitalized on the INT's key competence, i.e., management for deployment projects. In addition, in the case of complex deployment projects, the INT provided the AVR with the customer's requirements for specifications within the scope of those needed by the AVR to implement the project as a subcontractor (Table 7).

Table 7: Deliver, products, and services of the integrator (INT) model supporting added value reseller (AVR) objectives

\begin{tabular}{|c|c|c|c|c|c|c|}
\hline \multirow{3}{*}{\begin{tabular}{|l} 
No. \\
4.0.
\end{tabular}} & \multirow{2}{*}{\multicolumn{2}{|c|}{ Deliver Products and Services of INT }} & \multicolumn{4}{|c|}{ AVR objectives } \\
\hline & & & \multirow{2}{*}{$\frac{I}{\bullet \bullet}$} & \multirow{2}{*}{$\begin{array}{ll}\text { II } \\
\bullet \bullet \\
\bullet \bullet\end{array}$} & \multirow{2}{*}{ III } & \multirow{2}{*}{$\frac{\text { IV }}{\bullet \bullet}$} \\
\hline & 10005 & Deliver Products and Services & & & & \\
\hline \multirow{3}{*}{ 4.3. } & \multirow{3}{*}{$\begin{array}{l}\text { Procure } \\
\text { materials and } \\
\text { services }\end{array}$} & $\begin{array}{l}\text { - Select suppliers and develop/maintain } \\
\text { contracts (10278) }\end{array}$ & - & $\circ$ & - & ০ \\
\hline & & - Order materials and services (10279) & - & - & - & $\circ$ \\
\hline & & - Manage suppliers (10280) & - & $\circ$ & - & $\circ$ \\
\hline \multirow{4}{*}{4.4 . } & \multirow{4}{*}{$\begin{array}{l}\text { Deliver service } \\
\text { to customer }\end{array}$} & $\begin{array}{l}\text { - Confirm specific service requirements for } \\
\text { individual customer (10320) }\end{array}$ & ০০ & $\begin{array}{c}00 \\
0\end{array}$ & ○ & - \\
\hline & & $\begin{array}{l}\text { - Identify and schedule resources to meet } \\
\text { service requirements (10321) }\end{array}$ & - & ०० & $\circ$ & - \\
\hline & & $\begin{array}{l}\text { Provide services to specific customers } \\
(10322)\end{array}$ & - & 0 & ○ & - \\
\hline & & - Ensure quality of service (10323) & ০ & $\begin{array}{ll}00 \\
\circ \circ\end{array}$ & ○ & $\circ$ \\
\hline
\end{tabular}

$\bullet \bullet \bullet$ - strong impact of the INT processes on the AVR objectives; $\bullet \bullet-$ significant impact of the INT processes on the AVR objectives; • - marginal impact of the INT processes on the AVR objectives; $0000-$ crucial impact of the INT sub-processes on the AVR objectives; ○०० - strong impact of the INT sub-processes on the AVR objectives; ०० - significant impact of the INT sub-processes on the AVR objectives; $\bigcirc$ - marginal impact of the INT sub-processes on the AVR objectives; - no impact of the INT sub-processes on the AVR objectives;

\section{Source: Authors}

This reduced the AVR's risk of underestimating the level of the customer's expectations and, at the same time, built competences in the potential market for the AVR's services. As part of the processes relating to the INT procurement of materials and services, significant benefits resulting from potential opportunities were associated with the co-financing of purchases by the AVR for components (e.g., licenses). Depending on the volume and complexity of a deployment project, taking advantage of an INT's experience when negotiating contractual terms, can significantly assist in accomplishing the AVR's financial objectives.

Manage Customer Service

The third INT process group, important from the AVR's point of view, comprised processes relating to customer after-sales service (Table 8). The INT was the first line of customer support, while the more serious service requests were referred to the AVR to solve. At the same time, the INT, being close to 
the customer's problems, was able to meet the customer's subsequent expectations, thus ensuring additional sales for the AVR.

Table 8: Manage customer service of the integrator (INT) model supporting added value reseller (AVR) objectives

\begin{tabular}{|c|c|c|c|c|c|c|}
\hline \multirow[t]{2}{*}{ No. } & \multicolumn{2}{|c|}{ Manage Customer Service of INT } & \multicolumn{4}{|c|}{ AVR objectives } \\
\hline & & & $\mathbf{I}$ & II & III & IV \\
\hline 5.0. & 10006 & Manage Customer Service & $\bullet \bullet$ & $\stackrel{\bullet \bullet}{\bullet}$ & $\bullet$ & $\bullet$ \\
\hline \multirow{2}{*}{5.1 . } & \multirow{2}{*}{$\begin{array}{l}\text { Develop customer } \\
\text { care/customer service } \\
\text { strategy }\end{array}$} & $\begin{array}{l}\text { - Develop customer service } \\
\text { segmentation/prioritization (10381) }\end{array}$ & ০০ & - & 0 & - \\
\hline & & $\begin{array}{l}\text { - Establish service levels for customers } \\
(10383)\end{array}$ & ० & ০০ & - & $\circ$ \\
\hline \multirow{3}{*}{5.2.} & \multirow{3}{*}{$\begin{array}{l}\text { Plan } \\
\text { and manage customer } \\
\text { service operations }\end{array}$} & $\begin{array}{l}\text { - Plan and manage customer service work } \\
\text { force (10379) }\end{array}$ & - & 0 & - & - \\
\hline & & $\begin{array}{l}\text { - Manage customer service requests } \\
(10388)\end{array}$ & ০ & ০০ & - & - \\
\hline & & - Manage customer complaints (10389) & ০০ & $\begin{array}{c}\circ \\
\circ\end{array}$ & - & - \\
\hline 5.3. & $\begin{array}{l}\text { Measure } \\
\text { and evaluate customer }\end{array}$ & $\begin{array}{l}\text { - Measure customer satisfaction with } \\
\text { product and services (10403) }\end{array}$ & ০ & ০০ & - & 0 \\
\hline
\end{tabular}

$\bullet \bullet \bullet-$ strong impact of the INT processes on the AVR objectives; $\bullet \bullet-$ significant impact of the INT processes on the AVR objectives; $\bullet$ - marginal impact of the INT processes on the AVR objectives; $000-$ strong impact of the INT sub-processes on the AVR objectives; ০০ - significant impact of the INT subprocesses on the AVR objectives; $\odot$ - marginal impact of the INT sub-processes on the AVR objectives; - no impact of the INT sub-processes on the AVR objectives

Source: Authors

Perspective on the Objectives of the Integrator (INT) Model

The operating processes of the AVR model were related to categories: Deliver Products and Services (10005) and Manage Customer Service (10006), as having the greatest importance for accomplishing strategic objectives of the INT model (Table 9). The remaining processes of the AVR model affected the business objectives of the INT model only marginally.

Table 9: Operating process groups of the added value reseller (AVR) model supporting integrator (INT) objectives

\begin{tabular}{|l|l|l|c|c|c|c||}
\hline No. & \multicolumn{3}{|c|}{ Operating process groups of the AVR } & \multicolumn{3}{|c||}{ INT objectives } \\
\cline { 5 - 8 } & \multicolumn{2}{|c|}{ IN } & II & III & IV \\
\hline 1.0. & 10002 & Develop Vision and Strategy & $\bullet$ & - & - & $\bullet$ \\
\hline 2.0. & 10003 & Develop and Manage Products and Services & $\bullet$ & $\bullet \bullet$ & $\bullet$ & $\bullet$ \\
\hline 3.0. & 10004 & Market and Sell Products and Services & $\bullet$ & - & - & - \\
\hline 4.0. & 10005 & Deliver Products and Services & $\bullet$ & $\bullet \bullet$ & - & $\bullet \bullet$ \\
\hline 5.0. & 10006 & Manage Customer Service & $\bullet$ & $\bullet \bullet \bullet$ & - & $\bullet$ \\
\hline
\end{tabular}

$\bullet \bullet \bullet \bullet$ - crucial impact of the AVR processes on the INT objectives; $\bullet \bullet \bullet$ - strong impact of the AVR processes on the INT objectives; $\bullet \bullet-$ significant impact of the AVR processes on the INT objectives; $\bullet-$ marginal impact of the AVR processes on the INT objectives; - no impact of the AVR processes on the INT objectives

Source: Authors 
The analysis implied that the key processes of the AVR model supported the operating objectives of the INT model that were related to project profitability, to a great extent, and its market-related and financial objectives, to a much lesser extent.

Develop Vision and Strategy

The AVR processes relating to the analysis and assessment of the market environment and response to customers' changing needs should support long-term market-related objectives of the INT model, taking into consideration the non-competitive market strategies of both models, as shown in Table 10.

Table 10: Develop, vision, and strategy of the added value reseller (AVR) model supporting integrator (INT) objectives

\begin{tabular}{|c|c|c|c|c|c|c|}
\hline \multirow{3}{*}{\begin{tabular}{|l} 
No. \\
1.0.
\end{tabular}} & \multirow{2}{*}{\multicolumn{2}{|c|}{ Develop Vision and Strategy of AVR }} & \multicolumn{4}{|c|}{ INT objectives } \\
\hline & & & \multirow{2}{*}{$\begin{array}{c}\text { I } \\
\bullet \bullet\end{array}$} & \multirow{2}{*}{$\begin{array}{l}\text { II } \\
-\end{array}$} & \multirow{2}{*}{$\begin{array}{c}\text { III } \\
-\end{array}$} & \multirow{2}{*}{ IV } \\
\hline & 10002 & Develop Vision and Strategy & & & & \\
\hline \multirow{2}{*}{1.1.} & \multirow{2}{*}{$\begin{array}{l}\text { Define the } \\
\text { business concept }\end{array}$} & - Assess the external environment (10017) & ০ & - & - & - \\
\hline & & - Survey market and determine customer needs (10018) & $\circ$ & - & - & - \\
\hline \multirow{2}{*}{1.2.} & \multirow{2}{*}{$\begin{array}{l}\text { Develop business } \\
\text { strategy }\end{array}$} & - Evaluate strategic options to achieve the objectives (10038) & ০০ & - & - & 0 \\
\hline & & - Select long-term business strategy (10039) & ০০ & - & - & ० \\
\hline
\end{tabular}

$\bullet \bullet$ - significant impact of the AVR processes on the INT objectives; $\bullet$ - marginal impact of the AVR processes on the INT objectives; - no impact of the AVR processes (sub-processes) on the INT objectives ; ०० - significant impact of the AVR sub-processes on the INT objectives; ○ - marginal impact of the AVR sub-processes on the INT objectives

Source: Authors

Develop and Manage Products and Services

The AVR processes associated with developing new software and new applications for existing solutions could support both market-related objectives, and operating and financial objectives of the INT model. The achievement from a synergistic effect of the processes depends on their convergence (Table 11).

Table 11: Develop and manage products and services of the added value reseller (AVR) model supporting integrator (INT) objectives

\begin{tabular}{|c|c|c|c|c|c|c|}
\hline \multirow{3}{*}{\begin{tabular}{|l} 
No. \\
2.0.
\end{tabular}} & \multirow{2}{*}{\multicolumn{2}{|c|}{$\begin{array}{c}\text { Develop and Manage Products and Services } \\
\text { of AVR }\end{array}$}} & \multicolumn{4}{|c|}{ INT objectives } \\
\hline & & & \multirow[t]{2}{*}{$\mathbf{I}$} & \multirow{2}{*}{ II } & \multirow{2}{*}{ III } & \multirow{2}{*}{$\begin{array}{l}\text { IV } \\
\text { • }\end{array}$} \\
\hline & 10003 & Develop and Manage Products and Services & & & & \\
\hline \multirow{3}{*}{2.1.} & \multirow{3}{*}{$\begin{array}{l}\text { Manage product } \\
\text { and service portfolio }\end{array}$} & - Evaluate performance of existing services (10063) & $\circ$ & ০ & - & $\circ$ \\
\hline & & $\begin{array}{l}\text { - Define product/service development requirements } \\
\text { (10064) }\end{array}$ & - & 0 & 0 & - \\
\hline & & - Manage product and service life cycle (10067) & $\circ$ & ০ & $\circ$ & $\circ$ \\
\hline \multirow{3}{*}{2.2 . } & \multirow{3}{*}{$\begin{array}{l}\text { Develop products } \\
\text { and services }\end{array}$} & $\begin{array}{l}\text { - Design, build and evaluate products and services } \\
\text { (10080) }\end{array}$ & 0 & 0 & 0 & 0 \\
\hline & & $\begin{array}{l}\text { - Test market for new or revised product and services } \\
\text { (10081) }\end{array}$ & - & - & - & - \\
\hline & & - Prepare for production (10082) & - & - & - & - \\
\hline
\end{tabular}

$\bullet \bullet$ - significant impact of the AVR processes on the INT objectives; $\bullet$ - marginal impact of the AVR processes on the INT objectives; - no impact of the AVR processes (sub-processes) on the INT objectives; $० \circ$ - significant impact of the AVR sub-processes on the INT objectives; $~-$ marginal impact of the AVR sub-processes on the INT objectives

Source: Authors 


\section{Market and Sell Products and Services}

Studies demonstrate that the situation of having AVR as the ordering party for the INT is very rare. Accordingly, the AVR processes, relating to marketing and sales, supported the strategic objectives of the INT model to a relatively small degree (Table 12).

Table 12: Market and sell products and services of the added value reseller (AVR) model supporting integrator (INT) objectives

\begin{tabular}{|c|c|c|c|c|c|c|}
\hline \multirow{3}{*}{\begin{tabular}{|l} 
No. \\
3.0.
\end{tabular}} & \multirow{2}{*}{\multicolumn{2}{|c|}{ Market and Sell Products and Services of AVR }} & \multicolumn{4}{|c|}{ INT objectives } \\
\hline & & & \multirow{2}{*}{ I } & \multirow{2}{*}{ II } & \multirow{2}{*}{$\begin{array}{l}\text { III } \\
-\end{array}$} & \multirow{2}{*}{$\begin{array}{c}\text { IV } \\
-\end{array}$} \\
\hline & 10004 & Market and Sell Products and Services & & & & \\
\hline \multirow{2}{*}{3.1.} & \multirow{2}{*}{$\begin{array}{l}\text { Understand markets, } \\
\text { customers, and } \\
\text { capabilities }\end{array}$} & $\begin{array}{l}\text { - Perform customer and market intelligence analys is } \\
(10106)\end{array}$ & O० & - & - & - \\
\hline & & - Evaluate and prioritize market opportunities (10107) & O & - & - & - \\
\hline \multirow{2}{*}{ 3.2. } & \multirow{2}{*}{$\begin{array}{l}\text { Develop marketing } \\
\text { strategy }\end{array}$} & - Define offering and customer value proposition (11168) & ○ & - & - & - \\
\hline & & $\begin{array}{l}\text { - Define pricing strategy to align to value proposition } \\
(10123)\end{array}$ & O & - & - & - \\
\hline \multirow{2}{*}{3.3} & \multirow{2}{*}{ Develop sales strategy } & - Develop sales partner/alliance relationships (10130) & - & - & - & - \\
\hline & & - Develop and manage sales plans (10105) & ○ & - & - & - \\
\hline \multirow{3}{*}{$\beta .5}$. & \multirow{3}{*}{$\begin{array}{l}\text { Develop and manage } \\
\text { sales plans }\end{array}$} & - Generate leads (10182) & - & - & - & - \\
\hline & & - Manage customer sales (10184) & - & - & - & - \\
\hline & & - Manage sales force (10186) & - & - & - & - \\
\hline
\end{tabular}

$\bullet \bullet$ - significant impact of the AVR processes on the INT objectives; - no impact of the AVR processes (sub-processes) on the INT objectives; ○ - significant impact of the AVR sub-processes on the INT objectives; ○ - marginal impact of the AVR sub-processes on the INT objectives

Source: Authors

Assuming a convergence of market strategies for the AVR and INT models, the AVR processes for understanding and analyzing customers' needs may supplement those supporting strategic marketrelated objectives of the INT model.

Deliver Products and Services

The primary AVR processes supporting the INT objectives were associated with delivery of products and services to customers, as part of the implementation of the INT's deployment projects (Table 13).

Table 13: Deliver products and services of the added value reseller (AVR) model supporting integrator (INT) objectives

\begin{tabular}{|c|c|c|c|c|c|c|}
\hline \multirow{3}{*}{\begin{tabular}{|l} 
No. \\
4.0.
\end{tabular}} & \multirow{2}{*}{\multicolumn{2}{|c|}{ Deliver Products and Services of AVR }} & \multicolumn{4}{|c|}{ INT objectives } \\
\hline & & & \multirow{2}{*}{$\begin{array}{l}\text { I } \\
\bullet\end{array}$} & \multirow{2}{*}{$\begin{array}{l}\text { II } \\
\bullet \bullet \\
\bullet \bullet\end{array}$} & \multirow{2}{*}{ III } & \multirow{2}{*}{$\begin{array}{l}\text { IV } \\
\bullet \bullet\end{array}$} \\
\hline & 10005 & Deliver Products and Services & & & & \\
\hline \multirow{4}{*}{4.4 . } & \multirow{4}{*}{$\begin{array}{l}\text { Deliver service } \\
\text { to customer }\end{array}$} & $\begin{array}{l}\text { - Confirm specific service requirements for individual } \\
\text { customer (10320) }\end{array}$ & - & $\circ$ & - & 0 \\
\hline & & $\begin{array}{l}\text { - Identify and schedule resources to meet service } \\
\text { requirements (10321) }\end{array}$ & - & ০ & - & - \\
\hline & & - Provide service to specific customers (10322) & ০ & $\begin{array}{l}\circ \\
\circ \circ\end{array}$ & - & ০ \\
\hline & & - Ensure quality of service (10323) & - & - & - & - \\
\hline
\end{tabular}

$\bullet \bullet \bullet \bullet$ - crucial impact of the AVR processes on the INT objectives; $\bullet \bullet$ - significant impact of the AVR processes on the INT objectives; - no impact of the AVR processes (sub-processes) on the INT objectives; $০ 000$ - crucial impact of the AVR sub-processes on the INT objectives; ○০ - significant impact of the AVR sub-processes on the INT objectives; ○marginal impact of the AVR sub-processes on the INT objectives

Source: Authors 
Here, the integrator (INT) takes advantage of the AVR's specialist competences and focuses on ensuring high quality services from all vendors for the project. At the same time, such an approach supported development of a market for services of the INT with the AVR as a subcontractor. Ultimately, the INT financial objectives, with reference to the processes group in question, were accomplished through: (1) shortening the duration of the deployment project owing to the best possible identification of the customer's requirements and (2) financing the INT's operations with vendors' loans (primarily through the AVR).

\section{Manage Customer Service}

In terms of managing customer services (Table 14), in the examined approach, the AVR was either the second or third customer support line (the INT is usually the first line of support).

Table 14: Manage Customer Service of the added value reseller (AVR) model supporting integrator (INT) objectives

\begin{tabular}{|c|c|c|c|c|c|c|}
\hline \multirow{3}{*}{\begin{tabular}{|l} 
No. \\
5.0.
\end{tabular}} & \multirow{2}{*}{\multicolumn{2}{|c|}{ Manage Customer Service of AVR }} & \multicolumn{4}{|c|}{ INT objectives } \\
\hline & & & \multirow[b]{2}{*}{$\bullet \bullet$} & \multirow{2}{*}{ II } & \multirow{2}{*}{ III } & \multirow{2}{*}{ IV } \\
\hline & 10006 & Manage Customer Service & & & & \\
\hline \multirow[t]{2}{*}{ 5.1. } & \multirow{2}{*}{$\begin{array}{l}\text { Develop customer } \\
\text { care/customer } \\
\text { service strategy }\end{array}$} & $\begin{array}{l}\text { - Develop customer service } \\
\text { segmentation/prioritization (10381) }\end{array}$ & - & - & - & - \\
\hline & & - Establish service levels for customers (10383) & - & - & - & - \\
\hline \multirow{3}{*}{5.2 . } & \multirow{3}{*}{$\begin{array}{l}\text { Plan and manage } \\
\text { customer service } \\
\text { operations }\end{array}$} & $\begin{array}{l}\text { - Plan and manage customer service work force } \\
\text { (10379) }\end{array}$ & 00 & $\begin{array}{c}\circ \\
\circ\end{array}$ & - & 0 \\
\hline & & - Manage customer service requests (10388) & - & - & - & - \\
\hline & & - Manage customer complaints (10389) & - & - & - & - \\
\hline 5.3. & $\begin{array}{l}\text { Measure and } \\
\text { evaluate customer } \\
\text { service operations }\end{array}$ & $\begin{array}{l}\text { - Measure customer satisfaction with products } \\
\text { and services } \\
\text { (10403) }\end{array}$ & - & - & - & - \\
\hline
\end{tabular}

$\bullet \bullet \bullet$ - strong impact of the AVR processes on the INT objectives; $\bullet \bullet-$ significant impact of the AVR processes on the INT objectives; - - marginal impact of the AVR processes on the INT objectives ; - no impact of the AVR processes (sub-processes) on the INT objectives; O o - strong impact of the AR subprocesses on the INT objectives; ० - significant impact of the AVR sub-processes on the INT objectives; $\bigcirc-$ marginal impact of the AVR sub-processes on the INT objectives

Source: Authors

Therefore, the operating objectives of the INT model, supported by AVR processes, were focused on ensuring the continuous operation of deployed solutions on the basis of service level agreement terms, agreed upon by the customer (Table 14). The risk associated with observing service level agreement terms was transferred almost entirely to the AVR. However, the INT still bore the risk associated with the reputation, resulting from the quality of service provided to the end user. Hence, the remaining processes of this group, i.e., associated with the negotiations of service level agreement terms, the management of service requests, and customer complaints were within the INT's domain.

\section{Integration Risk Assessment}

The authors assessed the risk of integrating selected business models using the classical strengths, weaknesses, opportunities, and threats (SWOT) analysis, to examine the impact of the analyzed model on all models in the enterprise group.

In the analyzed example, both the AVR and the INT pursued a similar competitive strategy, focused on the integration with the customer. However, the INT was 'closer to the customer' due to its position in the value chain of the sector. This meant, among other implications, that the AVR was more often the INT's subcontractor, and not vice versa. This thesis is confirmed by analyzing the impact of the AVR processes on the INT objectives. As part of the integration and at the same time, cooperation, the 
INT benefited from the AVR's technological competences, which, when combined with the supervision of the deployment by the INT, ensured high profitability of implemented projects. Inversely, the INT was a convenient distribution channel for the AVR, building the market through subsequently tying the customer to the AVR (through maintenance services provided mostly by the AVR). The INT's vendor verification posed a serious threat to the AVR, as the INT selected vendors based on requirements that were defined at the analysis stage for customer needs. The INT will not recognize the needs of its customers from the point of view of the AVR's competences. However, it will select vendors in such a way as to generate the largest profits from the project. Inversely, technical support services that connected the AVR with the INT's customers, posed a threat for the INT on the part of the AVR, as the INT, in many cases, was not able to provide such services alone and must rely on those of the AVR.

\section{Conclusion}

The Polish MIS sector has key business models that are recognized for providing customer value. These models include the 'integrator' and the 'added value reseller', which are supported by other active business models and build the foundations of value for various stakeholders. Observing the financial condition of added value resellers and integrators based on their functions in the value chain, can contribute towards developing a system for early diagnosis of opportunities and threats for an enterprise group.

Combining businesses into groups should be preceded by an in-depth analysis of the impact of key processes of the acquired business model on those of the acquirer and the group's companies. To achieve this objective, it is necessary to analyze the impact of the key processes of one model on the strategic objectives of another, and subsequently to assess the opportunities and threats relating to the combined models.

From examining the accomplishment of the strategic objectives for the added value reseller from the view point of the integrator's processes, one can conclude that the processes involving the delivery of products and services generated the greatest added value for the integrator's complex deployment projects. In addition, the integrator's marketing and sales processes significantly affect the development of the market for the added value reseller. However, the processes of developing and managing products or services may not support the strategic objectives for the added value reseller to any significant extent.

The operating processes for the added value reseller, which involves the delivery of products and services and customer service management, can rank high in terms of achieving the integrator's strategic objectives. In this study, the basic processes for the added value reseller, which involve the delivery of products and services, strongly supported the accomplishment of the integrator's operating objectives for ensuring project profitability. However, in the case of the added value reseller, no significant support for achieving the integrator's market-related and financial objectives was evident.

This study's assessment of the risk of integrating business models, using the classical SWOT analysis, explained the mutual interactions between the business models. On the one hand, through integration and cooperation, the integrator capitalized on the technological competences of the added value reseller, and this, when combined with the supervision of the deployment process by the integrator, translated into high profitability for the implemented projects. On the other hand, the integrator was a convenient distribution channel for the added value reseller, building the market through the subsequent tying of the customer to the added value reseller. However, the integrator's vendor verification processes posed a serious threat to the added value reseller.

In the area of methodological improvement and on the basis of past experience, the authors propose to increase the role of quantitative methods in future research. Ongoing studies will be mainly aimed at developing methodological assumptions for performance measurement in terms of creating value in enterprise groups.

The methodology presented in this paper could help develop a computer system supporting strategic decisions about allocating resources in complex organizations. In the case of a greater number of models (more than three), the quantity of required combinations grows rapidly. Thus, a substantial need to develop an IT tool supporting business combination processes is one possible implication (or limitation) of this paper. 


\section{References}

APQC (2015, October). Process Classification Framework (PCF) - Cross-Industry - PDF Version 6.1.1. Retrieved March 31, 2016, from https://www.apqc.org/knowledge-base/documents/apqc-process-classification-framework-pcf-cross-industry-pdfversion-611

Birkinshaw, J., \& Ansari, S. (2015). Understanding Management Models. Going Beyond "What" and "Why" to "How" Work Gets Done in Organizations. In Foss, J.N., \& Saebi, T. (2015). Business Model Innovation. The organizational Dimension. Oxford: Oxford University Press, 85-99.

Bouman, H., Faber, E., Haaker, T., \& de Reuver M. (2008). Conceptualizing the STOF Model. In Bouwman, H., de Vos, M., \& Haaker, T. (2008). Mobile Service Innovation and Business Models. Berlin Heidelberg: Springer, 31-70.

Casadesus-Masanell, R., \& Ricart, J. E. (2010). From Strategy to Business Models and onto Tactics. Long Range Planning, 43, 195-212. DOI:10.1016/j.lrp.2010.01.004

Casadesus-Masanell, R., \& Zhu, F. (2013). Business model innovation and competitive Imitation: the case of sponsor-based business models. Strategic Management Journal, 34(4), 464-480. DOI:10.1002/smj.2022

Cavalcante, S. A., Kesting, P., \& Ulhøi, A. (2011). Business model dynamics and innovation: (re)establishing the missing linkages. Management Decision, 49 (8), 1327-1337. DOI: 10.1108/00251741111163142

Central Statistical Office. (2015). Enterprise groups in Poland in 2014,26-45. Retrieved March, 31, 2016, from http://stat.gov.pl/obszary-tematyczne/podmioty-gospodarcze-wyniki-finansowe/przedsiebiorstwa-niefinansowe/grupyprzedsiebiorstw-w-polsce-w-2014-r-,14,7.html

Central Statistical Office. (2016a). Business Tendency Survey in Industry, Trade and Services in March 2016. Retrieved March, 31, 2016, 15, from http://stat.gov.pl/obszary-tematyczne/koniunktura/koniunktura/koniunktura-w-przemyslebudownictwie-handlu-i-uslugach-w-marcu-2016-roku,3,40.html

Central Statistical Office. (2016b). Business Tendency Survey in Services - current database - monthly data, 6. Retrieved March, 31, 2016, from http://stat.gov.pl/obszary-tematyczne/koniunktura/koniunktura/koniunktura-w-przemyslebudownictwie-handlu-i-uslugach-2000-2016,4,8.html

Chatterjee, S., \& Brueller, N. N. (2015). A new M\&A methodology: five lessons in anticipating post-merger resource interactions and challenges. Strategy \& Leadership, 43 (4), 33. Doi: 10.1108/SL-04-2015-0031

Chesbrough, H. (2010). Business model innovation: Opportunities and barriers. Long Range Planning, 43, 355-362.

Doi:10.1016/j.lrp.2009.07.010

Chesbrough, H., \& Rosenbloom, R. S. (2002). The role of the business model in capturing value from innovation: Evidence from Xerox corporation's technology spin-off companies. Industrial and Corporate Change, 11 (3), 530-549.

Dottore, F. A. (1977, October 31). Data base provides business model. Computerworld, S/2-S/12.

Holloway, S. S, \& Sebastiao, H. J. (2010). The role of business model innovation in the emergence of markets: A missing dimension of entrepreneurial strategy. Journal of Strategic Innovation and Sustainability, 6(4), 87-96.

Konczal, E. (1975). Models are for managers, not mathematicians. Journal of Systems Management, 26 (1), 212.

Markides, C. C. (2008). Game-changing strategies. How to create new market space in established industries by breaking the rules. San Francisco: Jossey Bass, 1-184.

Morris, M., Schindehutte M., Richardson, J., \& Allen, J. (2006). Is the business model a useful strategic concept?

Conceptual, theoretical, and empirical insights. Journal of Small Business Strategy, 17 (1), 28-40.

Normann, R., \& Ramirez, R. (1993, July-August). From Value Chain to Value Constellation: Designing lnteractive Strategy. Harvard Business Review, 68-69.

Osterwalder, A., \& Pigneur, Y. (2012). Business model generation: a handbook for visionaries. Gliwice: Helion. (Original work published 2010), 18-55[in Polish].

Sanchez, P., \& Ricart, J. E. (2010). Business model innovation and sources of value creation in low-income markets. European Management Review, 139-147. DOI: 10.1057/emr.2010.16

Shin, J., \& Park, Y. (2009). Both business process and customer value have been continuously emphasized, and are thus central to business model variants. Industrial Marketing Management, 38 (3), 324-334. DOI:

10.1016/j.indmarman.2007.06.017

Sniukas, M. (2012). Making business model innovation happen. Applied Innovation Management, 8-26, Retrieved March, 31, 2016, from

http://static1.squarespace.com/static/5746c39acf80a16fc7ab8ebc/t/5748635f62cd9455e48eaeb7/1464361828382/IMID2012002-how-to-make-business-innovation-happen-sniukas.pdf

Stähler , P. (2002). Geschäftsmodelle in der digitalen Ökonomie. Köln: JOSEF EUL, 37-39.

Sustainability Accounting Standards Board, 2014. Software \& IT Services. Research Brief. 2-3, Retrieved March, 31, 2016, from http://www.sasb.org/wp-content/uploads/2014/05/SASB_Software-IT_Brief.pdf

Teece, D. (2010). Business models, business strategy and innovation. Long Range Planning, 43, 183-187.

DOI:10.1016/j.lrp.2009.07.003

Treacy, M., \& Wiersema, F. (1997). Marktführerschaft: Wege zur Spitze. München: Heyne, 10.

Vester, F., \& Hesler, A. (1980). Sensitivitätsmodell. Frankfurt am Main: Regionale Planungsgemeinschaft, 271-277.

Wartini-Twardowska, J. (2014). Consolidation in Groups from the Perspective of Business Models, using the Sector of Management Information System Producers as a Case.. Warszawa: C.H. Beck, 98-336 [in Polish].

Wirtz, B. W. (2011). Business Model Management. Design - Instrumente - Erfolgsfaktoren von Geschäftsmodellen. Wiesbaden: Gabler, 22-299.

Zott, C., \& Amit, R. (2008). The fit between product market strategy and business model: implications for firm performance. Strategic Management Journal, 29 (1), 1-5. DOI: 10.1002/smj.642 